Table VII. Surface Tension, $\gamma\{\mathrm{dyn} / \mathrm{cm}\}$, of Leucine Solutions at $20^{\circ} \mathrm{C}$ as a Function of Concentration and Cosolute

\begin{tabular}{ccc}
\hline concn, mol $/ \mathrm{L}$ & $\begin{array}{c}\text { aqueous } \\
\text { solution }\end{array}$ & $\begin{array}{c}\text { saturated glycine } \\
\text { solution }(22.8 \mathrm{~g} / 100 \mathrm{~mL})\end{array}$ \\
\hline 0 & 72.8 & 75.7 \\
0.05 & 72.1 & 72.1 \\
0.075 & 71.3 & 70.0 \\
0.1 & 70.0 & 69.2 \\
\hline
\end{tabular}

least $100 /$ batch in the presence of hydrophobic additives, while with hydrophilic ones all the crystals appeared at the bottom of the crystallizer.

Analytical Methods for Quantitative Evaluation of Crystal Orientations. Complete orientation of the glycine crystals was established by the following four independent methods:

a. Crystal Coloring. Crystallization experiments were carried out in the presence of very small amounts $(0.01 \% \mathrm{w} / \mathrm{w}$, which does not have any kinetic effect) of the resolved yellow dye $N^{t}-2,4$-dinitrophenyl-(S)-lysine, which is enantioselectively occluded into the $(010)$ oriented glycine crystals, thus imparting to them a yellow color. These crystals are easily differentiated visually from the non-colored $(0 \overline{1} 0)$ oriented counterpart.

b. Enantiomeric HPLC Measurements. Samples $(20 \mu \mathrm{L})$ were injected onto a reverse-phase column $(25 \mathrm{~cm} \times 4.6 \mathrm{~mm})$ self-packed with $5 \mu \mathrm{m}$ Nucleosil C18 (Macherey Nagel), with a mobile phase composition of an aqueous solution of cupric acetate $\left(4 \times 10^{-3} \mathrm{M}\right)$ and $N, N$-di-npropyl- $(S)$-alanine $\left(8 \times 10^{-3} \mathrm{M}\right)$ at $\mathrm{pH} 5.3-5.5 .^{16}$ The samples were prepared by dissolving the whole batch of floating crystals, after thorough washing in water, into the appropriate amounts of mobile phase.

c. Morphology of the Crystals. The $(010)$ and $(010)$ oriented glycine crystals assume an enantiomorphous morphology in two-dimensional projection at the interface and are therefore visually differentiable. This enantiomorphism arises from the fact that the $\beta$ angle is $112^{\circ}$ and that within the same batch the ratio of the lengths of the crystals along $a$ and $c$ is approximately constant.

d. Crystallographic Measurements. The direction of the crystallographic axes and the Miller indexes of the basal \{010\} faces were assigned by X-ray diffraction measurements on a Siemens diffractometer after the face exposed at the interface was marked. ${ }^{16}$
Methods a-c provide information on the degree of orientation of the entire batch of crystals. Method d which is absolute and unambiguous is only applicable to specimen crystal. Ten percent of each batch containing more than 100 crystals was routinely analized. In addition the few false negatives observed in methods a and $c$ (for example, those crystals which assume a rhombic habit or those which are too thin to occlude sufficient amount of dye) were singularly analyzed by method d.

Growth Experiments. In the experiments of growth from seeds, pairs of seeds of known size $(0.5 \times 1 \mathrm{~mm}$ area, $0.14-0.16 \mathrm{~mm}$ thickness $)$ were deposited with opposite $( \pm b)$ orientations on the surface of a $2.5 \%$ supersaturated glycine solution $(300 \mathrm{~mL}$ ) containing the appropriate additive (Table VI). The solution surface was divided in two compartments by aluminum foil in order to avoid contact between the seeds. Growth of the seeds was performed in closed vessels without stirring in an air thermostat at $26.5^{\circ} \mathrm{C}$, for a period of up to $48 \mathrm{~h}$. The grown crystals were removed and their thickness in the $b$ direction remeasured under an optical microscope $(\times 50)$. The relative growth along $b$ is represented by the ratio final:initial thickness.

Amplification Measurements. Crystallizations were performed as described above, both in excess of $(R)$ and $(S)$ additive. For each enantiomeric excess of the additive used, the appropriate concentration was determined which yields complete orientation of the glycine crystals. In the presence of high concentrations of leucine $(>1.5 \%)$ of low enantiomeric excess, the floating crystals of glycine are very thin plates. Their orientation was therefore confirmed by all four methods described above.

Surface Tension Measurements. These were performed on a semiautomatic Fisher surface tensiometer by the du Nouy method with use of a platinum iridium ring, for saturated solutions of glycine containing up to $0.1 \mathrm{~mol} / \mathrm{L}$ of additive.

Acknowledgment. We thank Prof. Z. Berkovitch-Yellin for discussions, E. Gati Shavit for her skillful help, the Israel Academy of Science and Humanities, the U.S.--Israel Binational Foundation, Jerusalem, and the donors of the Petroleum Research Fund, administrated by the American Chemical Society, for financial support. L.A. is a recipient of the Charles S. Revson Career Development Chair.

\title{
Thermochemical Study of the Addition of Carbenium Ions to Alkenes
}

\author{
Christian Schade, ${ }^{1 \mathrm{a}}$ Herbert Mayr, ${ }^{* 1 \mathrm{a}}$ and Edward M. Arnett ${ }^{\text {1b }}$ \\ Contribution from the Institut für Chemie der Medizinischen Universität zu Lübeck, Ratzeburger \\ Allee 160, D-2400 Lübeck, Federal Rupublic of Germany, and Department of Chemistry, Duke \\ University, Durham, North Carolina 27706. Received June 22, 1987
}

\begin{abstract}
Scales of carbenium ion stabilities have been obtained from ${ }^{1} \mathrm{H}$ NMR equilibrium studies of mixtures of partly ionized para-substituted diarylmethyl chlorides in $\mathrm{CD}_{2} \mathrm{Cl}_{2} / \mathrm{BCl}_{3}$ at $-70^{\circ} \mathrm{C}$ and via calorimetric determination of the heats of ionization $\left(\Delta H_{i}\right)$ of the alkyl chlorides $\left(\mathrm{Ar}_{2} \mathrm{CHCl}+\mathrm{BCl}_{3} \rightarrow \mathrm{Ar}_{2} \mathrm{CH}^{+} \mathrm{BCl}_{4}^{-}\right)$in $\mathrm{CH}_{2} \mathrm{Cl}_{2} / \mathrm{BCl}_{3}$ at $-70^{\circ} \mathrm{C}$. The heats of the

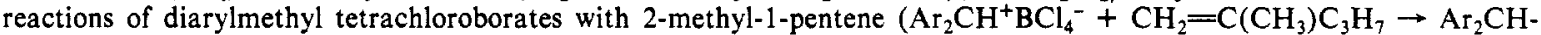
$\left.\mathrm{CH}_{2} \mathrm{C}\left(\mathrm{CH}_{3}\right) \mathrm{ClC}_{3} \mathrm{H}_{7}+\mathrm{BCl}_{3}\right)$, which were determined by low-temperature calorimetry, increase from $-53.1 \mathrm{~kJ} / \mathrm{mol}$ for $\left(\mathrm{H}_{3} \mathrm{CC}_{6} \mathrm{H}_{4}\right)_{2} \mathrm{CH}^{+} \mathrm{BCl}_{4}^{-}$to $-33.0 \mathrm{~kJ} / \mathrm{mol}$ for the better stabilized $\left(\mathrm{H}_{3} \mathrm{COC}_{6} \mathrm{H}_{4}\right)\left(\mathrm{H}_{3} \mathrm{CC}_{6} \mathrm{H}_{4}\right) \mathrm{CH}^{+} \mathrm{BCl}_{4}^{-}$. In contrast, the heats $\left(\Delta H_{\mathrm{a}}\right)$ of the Lewis acid catalyzed additions of the corresponding para-substituted diarylmethyl chlorides to 2-methyl-1-pentene are independent of the para substituents $\left(\Delta H_{\mathrm{a}}=-86.5 \pm 2.7 \mathrm{~kJ} / \mathrm{mol}\right)$. Similar values of $\Delta H_{\mathrm{a}}$ were obtained for the addition of $p$-anisylphenylmethyl chloride to trimethylethylene, styrene, $\beta$-methylstyrene, and isoprene. $\Delta H_{\mathrm{a}}$ is predominantly determined by the conversion of a $\pi(\mathrm{C}=\mathrm{C})$ into a $\sigma(\mathrm{C}-\mathrm{C})$ bond, and the heats of addition of diarylmethyl tetrachloroborates to alkenes in $\mathrm{CH}_{2} \mathrm{Cl}_{2}$ are given by the equation $\Delta H_{\mathrm{b}}=\left(9.5 \pm 6.3 \mathrm{p} K_{\mathrm{R}^{+}}\right) \mathrm{kJ} / \mathrm{mol}$.
\end{abstract}

Most synthetic reactions that yield carbon-carbon bonds proceed via polar mechanisms. Charged and neutral species may be used as synthetic equivalents of a- and d-synthons. ${ }^{2}$ One conceivable extreme, the reaction of carbenium ions with carbanions,

(1) (a) Medizinische Universität zu Lübeck. (b) Duke University.

(2) (a) Warren, S. Organic Synthesis: The Disconnection Approach; Wiley: New York, 1982. (b) Fuhrhop, J.; Penzlin, G. Organic Synthesis: Concepts, Methods, Starting Materials; Verlag Chemie: Weinheim, 1984. has recently been investigated in detail. ${ }^{3}$ In that system, the heats of reaction only depend on the stabilization energies of both ions $\left(\mathrm{p} K_{\mathrm{a}}\right.$ and $\left.\mathrm{p} K_{\mathrm{R}^{+}}\right)$, since the neutral products are characterized by approximately constant $\sigma(\mathrm{C}-\mathrm{C})$ bond increments. The addition

(3) (a) Arnett, E. M.; Molter, K. E. Acc. Chem. Res. 1985, 18, 339. (b) Arnett, E. M.; Chawla, B.; Amarnath, K.; Healy, M.; Molter, K. E. J. Am. Chem. Soc. 1985, 107, 5288. (c) Arnett, E. M.; Chawla, B.; Amarnath, K.; Whitesell, L. G., Jr. Energy Fuels 1987, 1, 17. 
Table I. NMR Spectroscopically Determined Equilibrium Constants and Free Energy Differences $\left(-70^{\circ} \mathrm{C} ; \mathrm{CD}_{2} \mathrm{Cl}_{2} / \mathrm{BCl}_{3}\right)$

\begin{tabular}{|c|c|c|}
\hline$X_{1}, Y_{1} / X_{2}, Y_{2}$ & $K_{203}$ & $\Delta G^{\circ}{ }_{203}, \mathrm{~kJ} / \mathrm{mol}$ \\
\hline $\mathrm{OCH}_{3}, \mathrm{OCH}_{3} / \mathrm{OCH}_{3}, \mathrm{OPh}$ & 0.014 & $7.2 \pm 0.3$ \\
\hline $\mathrm{OCH}_{3}, \mathrm{OPh} / \mathrm{OCH}_{3}, \mathrm{CH}_{3}$ & 0.049 & $5.1 \pm 0.3$ \\
\hline $\mathrm{OCH}_{3}, \mathrm{CH}_{3} / \mathrm{OCH}_{3}, \mathrm{H}$ & 0.025 & $6.2 \pm 0.1$ \\
\hline $\mathrm{OCH}_{3}, \mathrm{CH}_{3} / \mathrm{OPh}, \mathrm{CH}_{3}$ & 0.0098 & $7.8 \pm 0.3$ \\
\hline $\mathrm{OCH}_{3}, \mathrm{H} / \mathrm{OPh}, \mathrm{CH}_{3}$ & 0.50 & $1.2 \pm 0.1$ \\
\hline $\mathrm{OPh}, \mathrm{CH}_{3} / \mathrm{OPh}, \mathrm{H}$ & 0.026 & $6.2 \pm 0.1$ \\
\hline $\mathrm{OPh}_{2} \mathrm{CH}_{3} / \mathrm{OCH}_{3}, \mathrm{Cl}$ & 0.51 & $1.2 \pm 0.4$ \\
\hline $\mathrm{OPh}, \mathrm{H} / \mathrm{CH}_{3}, \mathrm{CH}_{3}$ & 0.26 & $2.3 \pm 0.3$ \\
\hline $\mathrm{OCH}_{3}, \mathrm{Cl} / \mathrm{CH}_{3}, \mathrm{CH}_{3}$ & 0.014 & $7.2 \pm 0.3$ \\
\hline
\end{tabular}

Table II. Comparison of Various Stability Scales of Para-Substituted Diarylcarbenium Ions $1^{+}-\mathrm{X}, \mathrm{Y}(\mathrm{kJ} / \mathrm{mol})$

\begin{tabular}{|c|c|c|c|c|c|}
\hline $\mathrm{X}, \mathrm{Y}$ & $\Delta \Delta G_{i}^{\circ G}$ & $\Delta H_{\mathrm{i}}^{b}$ & $\Delta G_{i}^{\circ c}$ & $\Delta H_{\mathrm{r}}^{\prime d}$ & $\mathrm{p} K_{\mathrm{R}}{ }^{e}$ \\
\hline $\mathrm{OCH}_{3}, \mathrm{OCH}_{3}$ & 0.0 & & & & -5.71 \\
\hline $\mathrm{OCH}_{3}, \mathrm{OPh}$ & 7.2 & & & & \\
\hline $\mathrm{OCH}_{3}, \mathrm{CH}_{3}$ & 12.3 & $-49.5 \pm 2.1$ & & & \\
\hline $\mathrm{OCH}_{3}, \mathrm{H}$ & 18.5 & $-45.4 \pm 2.9$ & & & -7.9 \\
\hline $\mathrm{OPh}, \mathrm{CH}_{3}$ & 19.7 & & & & \\
\hline $\mathrm{OCH}_{3}, \mathrm{Cl}$ & 20.9 & & & & \\
\hline $\mathrm{OPh}, \mathrm{H}$ & 25.9 & & -8.4 & & \\
\hline $\mathrm{CH}_{3}, \mathrm{CH}_{3}$ & 28.1 & $-32.6 \pm 2.5$ & -7.0 & $-175.4 \pm 3.8$ & -10.4 \\
\hline $\mathrm{CH}_{3}, \mathrm{H}$ & & & 3.0 & & -11.6 \\
\hline $\mathrm{H}, \mathrm{H}$ & & & & $-164.5 \pm 2.9$ & -13.3 \\
\hline $\mathrm{H}, \mathrm{Cl}$ & & & & & -13.7 \\
\hline $\mathrm{Cl}, \mathrm{Cl}$ & & & & $-148.6 \pm 3.3$ & -13.96 \\
\hline
\end{tabular}

${ }^{a}$ From equilibrium measurements in $\mathrm{CH}_{2} \mathrm{Cl}_{2} / \mathrm{BCl}_{3}$ at $-70^{\circ} \mathrm{C}$. Average error is $\pm 0.4 \mathrm{~kJ} / \mathrm{mol}$; this work. ${ }^{b} \mathrm{Heats}$ of ionization of the diarylmethyl chlorides in $\mathrm{CH}_{2} \mathrm{Cl} / \mathrm{BCl}_{3}$ at $-70{ }^{\circ} \mathrm{C}$; calorimetric investigation, this work. 'Free energy of ion pair formation in $\mathrm{CH}_{2} \mathrm{Cl}_{2} / \mathrm{BCl}_{3}$ at $-70^{\circ} \mathrm{C}$; from conductivity measurements. ${ }^{11}{ }^{d} \mathrm{Heats}$ of reaction of the diarylmethyl alcohols in $\mathrm{SO}_{2} \mathrm{Cl}_{2}, \mathrm{SbF}_{5} / \mathrm{FSO}_{3} \mathrm{H}(1: 1)$ at $-55^{\circ} \mathrm{C}$, calorimetric investigation. ${ }^{7 a}$ e From equilibrium measurements of the diarylmethyl alcohols in $\mathrm{H}_{2} \mathrm{SO}_{4}$ at $25^{\circ} \mathrm{C}^{6}$

of carbenium ions to alkenes is a related reaction type. The Lübeck group has recently developed methods to generate $1: 1$ addition products via Lewis acid catalyzed reactions of alkyl halides with alkenes, ${ }^{4}$ and the kinetics of the model reaction 1 have been studied. $^{s}$

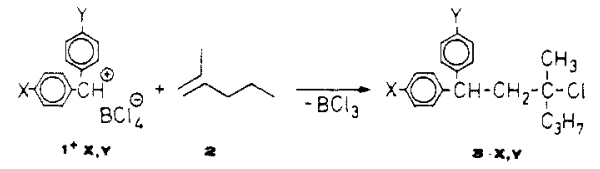

In this paper we present a thermochemical study of the ionization of diarylmethyl chlorides $(1-X, Y)$ and their addition reaction with alkenes.

1. Ionization of Diarylmethyl Chlorides. Equilibrium Studies-Free Energies of Ionization. Since the data on diaryl carbenium ion stabilities that are available refer to different media, ${ }^{6,7 a}$ we obtained a more comprehensive set of data by ${ }^{1} \mathrm{H}$

(4) (a) Mayr, H. Angew. Chem. 1981, 93, 202; Angew. Chem., Int. Ed. Engl. 1981, 20, 184. (b) Mayr, H.; Striepe, W. J. Org. Chem. 1983, 48, 1159. (c) Schneider, R. Diplomarbeit, Erlangen, 1984. (d) Mayr, H.; Schneider, R.; Pock, R. Makromol. Chem., Macromol. Symp. 1986, 3, 19. (e) See also: Olah, G. A.; Kuhn, S. J.; Barnes, D. G. J. Org. Chem. 1964, 29, 2685.

(5) (a) Schneider, R.; Grabis, U.; Mayr, H. Angew. Chem. 1986, 98, 94; Angew. Chem., Int. Ed. Engl. 1986, 25, 89. (b) Schneider, R.; Mayr, H. Angew. Chem. 1986, 98, 1033; Angew. Chem., Int. Ed. Engl. 1986, 25, 1016. (c) Mayr, H.; Schneider, R.; Grabis, U. Angew. Chem. 1986, 98, 1034; Angew. Chem., Int. Ed. Engl. 1986, 25, 1017. (d) Mayr, H.; Schneider, R. Macromol. Chem., Rapid Commun. 1984, 5, 43.

(6) (a) Franklin, J. L. In Carbonium Ions; Olah, G. A., Schleyer, P. v R., Eds.; Wiley: New York, 1968; Vol. I, p 77. (b) Liler, M. Reaction Mechanisms in Sulfuric Acid; Academic: New York, 1971. (c) Rochester, C. H. Acidity Functions; Academic: New York, 1970. (d) Deno, C.; Schriesheim, A. J. Am. Chem. Soc. 1955, 77, 3051 .

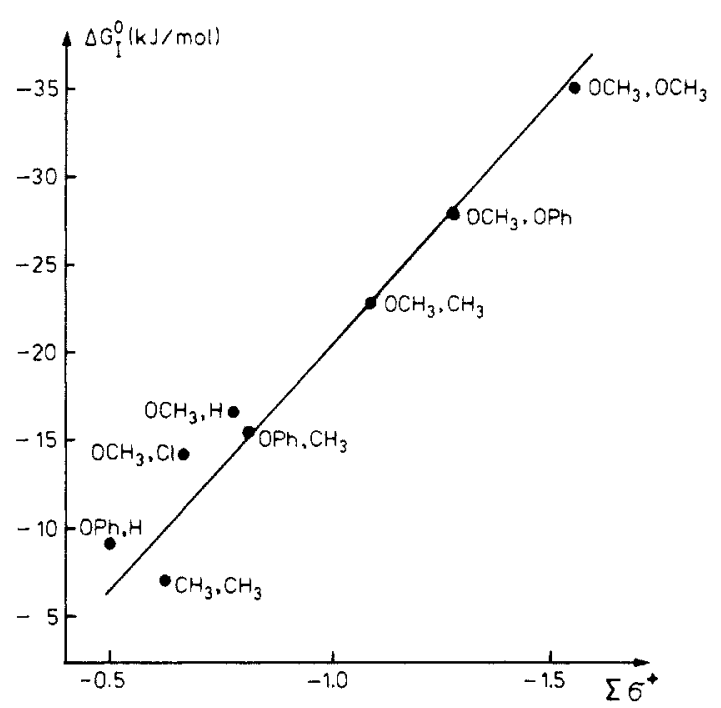

Figure 1. Correlation of the free energies of ionization $\left(\Delta G_{\mathrm{i}}^{\circ}\right)$ of parasubstituted diarylmethyl chlorides $1-\mathrm{X}, \mathrm{Y}$ in $\mathrm{CD}_{2} \mathrm{Cl}_{2} / \mathrm{BCl}_{3}$ at $-70^{\circ} \mathrm{C}$ versus the sum of $\sigma^{+}$values. The correlation equation $(r=0.980)$ is $\Delta G_{\mathrm{i}}{ }^{\circ}$ $=5+26 \sum \sigma^{+}(\mathrm{kJ} / \mathrm{mol})$.

Scheme I

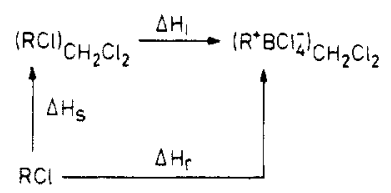

Table III. Heats of Ionization $\left(\Delta H_{\mathrm{i}}\right)$ of Para-Substituted Diarylmethyl Chlorides 1-X, $\mathrm{Y}$ in $\mathrm{CH}_{2} \mathrm{Cl}_{2} / \mathrm{BCl}_{3}$ at $-70{ }^{\circ} \mathrm{C}(\mathrm{kJ} / \mathrm{mol})$. Comparison of Relative Carbenium Ion Stabilities from Calorimetric $\left(\delta \Delta H_{\mathrm{i}}\right)$ and Equilibrium $\left(\delta \Delta G_{\mathrm{i}}^{\circ}\right)$ Studies

\begin{tabular}{lccccc}
\hline \multicolumn{1}{c}{$\mathrm{X}, \mathrm{Y}$} & $\Delta H_{\mathrm{r}}$ & $\Delta H_{\mathrm{s}}$ & $\Delta H_{\mathrm{i}}$ & $\delta \Delta H_{\mathrm{s}}$ & $\delta \Delta G_{\mathrm{i}}{ }^{\circ}$ \\
\hline $\mathrm{CH}_{3}, \mathrm{CH}_{3}$ & $-18.3 \pm 2.3$ & $14.4 \pm 1.0$ & $-32.6 \pm 2.5$ & 0 & 0 \\
$\mathrm{OCH}_{3}, \mathrm{H}$ & $-27.9 \pm 2.1$ & $17.4 \pm 2.0$ & $-45.4 \pm 2.9$ & -12.8 & -9.6 \\
$\mathrm{OCH}_{3}, \mathrm{CH}_{3}$ & $-36.2 \pm 2.0$ & $13.3 \pm 0.5$ & $-49.5 \pm 2.1$ & -16.9 & -15.8 \\
\hline
\end{tabular}

NMR spectroscopic studies of equilibria involving diarylmethyl tetrachloroborates in $\mathrm{CH}_{2} \mathrm{Cl}_{2}$ at $-70^{\circ} \mathrm{C}$.

If two cations are of similar stability, the equilibrium constant $K$ (eq 2) may be derived from the ratios of the species observed in the ${ }^{1} \mathrm{H}$ NMR spectrum (Table I). These data can be connected to give a scale of carbenium ion stabilities (column I, Table II).

$$
\mathrm{R}_{1}^{+}+\mathrm{R}_{2} \mathrm{Cl} \stackrel{K}{\rightleftharpoons} \mathrm{R}_{1} \mathrm{Cl}+\mathrm{R}_{2}^{+}
$$

In previous work, it has been shown that the heats of ionization of tertiary cumyl alcohols in $\mathrm{SbF}_{5}, \mathrm{FSO}_{3} \mathrm{H} / \mathrm{SO}_{2} \mathrm{ClF}$ at $-55^{\circ} \mathrm{C}$ are linearly correlated ${ }^{7 \mathrm{a}}$ with $\sigma^{+}$parameters. $^{8}$ Figure 1 shows that the free energies of ionization of diarylmethyl chlorides also give a fair correlation with $\sum \sigma^{+}$.?

The ${ }^{1} \mathrm{H}$ NMR shifts of the methine protons in the diarylcarbenium ions are correlated by $\delta=8.79+0.027 \Delta \Delta G_{i}^{\circ}$ to the relative carbenium ion stabilities of Table II.

Investigations of the temperature dependence of equilibrium reaction 2 are complicated by irreversible reactions taking place at elevated temperatures. Furthermore, rapid halide transfers, probably catalyzed by $\mathrm{BCl}_{4}^{-}$, lead to coalescences of $\mathrm{NMR}$ signals. Analysis of the temperature dependence of eq 2 between -70 and $-30{ }^{\circ} \mathrm{C}$ gave $\Delta \Delta S_{\mathrm{i}}=-3.1 \mathrm{~J} / \mathrm{K} \cdot \mathrm{mol}$ for $1-\mathrm{OMe}, \mathrm{Me} / 1-\mathrm{OMe}, \mathrm{H}$ and $\Delta \Delta S_{\mathrm{i}}=0.6 \mathrm{~J} / \mathrm{K} \cdot \mathrm{mol}$ for $1-\mathrm{OMe}, \mathrm{OPh} / 1-\mathrm{OMe}, \mathrm{Me}$. These numbers

(7) (a) Arnett, E. M.; Hofelich, T. C. J. Am. Chem. Soc. 1983, 105, 2889. (b) Arnett, E. M.; Petro, C. J. Am. Chem. Soc. 1978, 100, 5408. (c) Arnett, E. M.; Pienta, N. J. J. Am. Chem. Soc. 1980, 102, 3329.

(8) Stock, L. M.; Brown, H. C. Adv. Phys. Org. Chem. 1963, 1, 35.

(9) (a) Nishida, S. J. Org. Chem. 1967, 32, 2697. (b) Fox, J. R.; Kohnstam, G. Proc. Chem. Soc. London 1964, 115. 
Table IV. Heats of Addition of Para-Substituted Diarylmethyl Chlorides (1-X,Y) to 2-Methyl-1-pentene (2) in $\mathrm{CH}_{2} \mathrm{Cl}_{2}$ at $-70^{\circ} \mathrm{C}(\mathrm{kJ} / \mathrm{mol})$

\begin{tabular}{ccccccc}
\hline & \multicolumn{2}{c}{$\Delta H_{\mathrm{a}}$} & & & \\
\cline { 2 - 6 } para-subst X,Y in 1 & $\begin{array}{c}\text { procedure A, } \\
\text { Scheme II }\end{array}$ & $\begin{array}{c}\text { procedure B, } \\
\text { Scheme III }\end{array}$ & $\Delta H_{\mathrm{r}}(\mathrm{A})$ & $\Delta H_{\mathrm{r}}(\mathrm{B})$ & $\Delta H_{\mathrm{s}}(\mathrm{RCl})$ & $\Delta H_{\mathrm{c}}$ \\
\hline $\mathrm{OCH}_{3}, \mathrm{CH}_{3}$ & $-82.5 \pm 4.7$ & $-84.9 \pm 2.5$ & $-74.0 \pm 4.1$ & $-116.4 \pm 2.3$ & $13.3 \pm 0.5$ & $-44.8 \pm 0.9$ \\
$\mathrm{OCH}_{3}, \mathrm{H}$ & $-84.5 \pm 3.6$ & $-90.2 \pm 2.7$ & $-79.0 \pm 1.8$ & $-116.5 \pm 1.5$ & $17.4 \pm 2.0$ & $-43.7 \pm 1.0$ \\
$\mathrm{CH}_{3}, \mathrm{CH}_{3}$ & $-85.7 \pm 4.5$ & $-88.9 \pm 2.2$ & $-49.3 \pm 3.7$ & $-74.5 \pm 2.0$ & $14.4 \pm 1.0$ & 0 \\
$\mathrm{CH}_{3}, \mathrm{H}$ & & $-84.2 \pm 3.4^{b}$ & & $-69.8 \pm 3.3$ & & \\
$\mathrm{H}, \mathrm{H}$ & & $-90.9 \pm 0.9$ & & $-91.5 \pm 0.7^{c}$ & $-0.6 \pm 0.5$ & 0 \\
\hline
\end{tabular}

${ }^{a} \Delta H_{3}(2)=3.8 \pm 0.3 \mathrm{~kJ} / \mathrm{mol} .{ }^{b}$ Lewis acid: $\mathrm{ZnCl}_{2} \cdot\left(\mathrm{OEt}_{2}\right)_{1.5}{ }^{16}$ The heat of complexation of the product by the Lewis acid was assumed to be zero. ${ }^{c}$ Due to dissolution problems, some of the experiments were carried out with solutions of $1-\mathrm{X}$, in $\mathrm{CH}_{2} \mathrm{Cl}_{2}$. Prior to averaging, $\Delta H_{\mathrm{r}}$ was calculated according to $\Delta H_{\mathrm{r}}=\Delta H_{\mathrm{r}}^{\prime}+\Delta H_{\mathrm{s}}$ in these cases

show that the $T \Delta \Delta S_{\mathrm{i}}$ term is smaller than the error limits of $\Delta \Delta G_{\mathrm{i}}^{\circ}$ at $-70^{\circ} \mathrm{C}$. The data of Table I, therefore, represent differences in enthalpy, which can independently be determined by calorimetry.

Calorimetric Studies-Enthalpies of Ionization. The diarylmethyl chlorides listed in Table I are completely ionized in the presence of 1 (1-OMe, OMe)-200 (1-Me,Me) equiv of $\mathrm{BCl}_{3}$ in $\mathrm{CH}_{2} \mathrm{Cl}_{2}$ at $-70^{\circ} \mathrm{C}$, and we determined the heats of reaction $\left(\Delta H_{\mathrm{r}}\right)$ by breaking ampules of solid diarylmethyl chlorides $1-X, Y$ in the Lewis acid solution. According to Scheme $\mathrm{I}$, heats of ionization $\left(\Delta H_{\mathrm{i}}\right.$ ) can be obtained by correcting $\Delta H_{\mathrm{r}}$ for the integral heats of solution $\left(\Delta H_{\mathrm{s}}\right)$ of the pure diarylmethyl chlorides in $\mathrm{CH}_{2} \mathrm{Cl}_{2}$ (Table III). $\Delta H_{\mathrm{i}}$ was not dependent on the total ion concentration within the range of our study $\left(10^{-2}-10^{-3} \mathrm{M}\right)$, where ion pairing predominates. ${ }^{10.11}$

The comparison of $\Delta \Delta G_{\mathrm{i}}^{\circ}$ (equilibrium) and $\Delta H_{\mathrm{i}}$ (calorimetry) in Table III shows that both scales are parallel within the limits of experimental error $\left(\Delta \Delta G_{\mathrm{i}}{ }^{\circ}, \pm 0.4 \mathrm{~kJ} / \mathrm{mol} ; \Delta H_{\mathrm{i}}, \pm 2.5 \mathrm{~kJ} / \mathrm{mol}\right.$; average values). We conclude again that the differential entropies of ionization for two different diarylmethyl chlorides $\left[\Delta \Delta S_{\mathrm{i}}=\right.$ $\left.\Delta S_{\mathrm{i}}\left(\mathrm{R}_{1} \mathrm{Cl}\right)-\Delta S_{\mathrm{i}}\left(\mathrm{R}_{2} \mathrm{Cl}\right)\right]$ are close to zero. This relation has earlier been derived from $\mathrm{p} K_{\mathrm{R}^{+}} / \Delta H_{\mathrm{i}}$ correlations ${ }^{7 \mathrm{a}}$ and from correlations of solvolysis rates versus ionization enthalpies. ${ }^{12}$

While $\Delta \Delta S_{\mathrm{i}} \approx 0$, the absolute magnitude of $\Delta S_{\mathrm{i}}$ must be quite substantial, since 1-Me, $\mathrm{H}$ ionizes only partially in $\mathrm{BCl}_{3} / \mathrm{CH}_{2} \mathrm{Cl}_{2}$ at $-70^{\circ} \mathrm{C}$ though the ionization can be estimated to be exothermic by approximately $-25 \mathrm{~kJ} / \mathrm{mol}$ from $\mathrm{p} K_{\mathrm{R}^{+}}$(Table II). For the ionization of 1-Me,Me under these conditions $\Delta G_{i}{ }^{\circ}$ was derived to be $-7.0 \mathrm{~kJ} / \mathrm{mol} ;{ }^{11}$ with $\Delta H_{\mathrm{i}}=-32.6 \mathrm{~kJ} / \mathrm{mol}$ we obtain $\Delta S_{\mathrm{i}}=$ $-126 \mathrm{~J} / \mathrm{K} \cdot \mathrm{mol}$. Reported values for $\Delta S_{\mathrm{i}}$ range from -50 to -150 $\mathrm{J} / \mathrm{K} \cdot \mathrm{mol}^{13}$

Comparison of Different Carbenium Ion Stability Scales. Scales of carbenium ion stabilities have proven to be mutually convertible. ${ }^{3 a, 7 a}$ Heats of ionization of carbenium ion precursors in different Lewis acid media differ by a heat of transfer term $\left(\Delta H_{t}\right)$. $\Delta H_{t}$ is mainly determined by carbon-leaving group bonding, Lewis acid-leaving group bonding, Lewis acid-solvent bonding, and general dielectric solvation. $\Delta H_{\mathrm{t}}$ is constant for different cations, if they are solvated likewise within each medium. This is usually true for large, delocalized cations in nonnucleophilic media..$^{\mathrm{a}, \mathrm{b}, 14}$ Comparison of $\Delta H_{\mathrm{i}}$ for $1-\mathrm{Me}, \mathrm{Me}$ in $\mathrm{CH}_{2} \mathrm{Cl}_{2} / \mathrm{BCl}_{3}$ at $-70^{\circ} \mathrm{C}$ with the heat of ionization of the corresponding alcohol in $\mathrm{SbF}_{5}$, $\mathrm{HSO}_{3} \mathrm{~F}, \mathrm{SO}_{2} \mathrm{ClF}$ at $-55^{\circ} \mathrm{C}^{7 \mathrm{a}}$ yields $\Delta H_{\mathrm{t}}=-143 \mathrm{~kJ} / \mathrm{mol}$ for these media. With this number, we can convert the large variety of $\Delta H_{\mathrm{i}}$ data obtained in superacidic media into the $\mathrm{CH}_{2} \mathrm{Cl}_{2} / \mathrm{BCl}_{3}$ system to predict the feasibility of carbenium ion-alkene reactions in this medium.

The $\mathrm{p} K_{\mathrm{R}}+$ values $^{6 \mathrm{~d}}$ of four diaryl carbenium ions are linearly related to $\Delta H_{\mathrm{i}}$ (Figure 2). The slope of the correlation line, $\Delta H_{\mathrm{i}}$ $=m \mathrm{p} K_{\mathrm{R}^{+}}+b$, corresponds to that obtained in superacidic me-

(10) Arnett, E. M.; Hofelich, T. C. J. Am. Chem. Soc. 1982, 104, 3522. (11) Schneider, R.; Mayr, H.; Plesch, P. H. Ber. Bunsen Ges. Phys. Chem., in press.

(12) Arnett, E. M.; Petro, C.; Schleyer, P. v. R. J. Am. Chem. Soc. 1979, 101,5221 .

(13) (a) Heublein, G.; Bauerfeind, D. J. Prakt. Chem. 1984, 326, 81. (b)

Kessler, H,; Feigel, M. Acc. Chem. Res. 1982, 15, 2

(14) Arnett, E. M. J. Chem. Educ. 1985, 62, 385

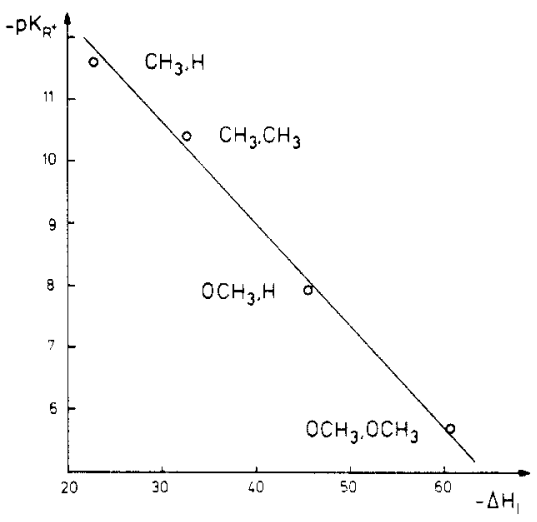

Figure 2. Correlation of heats of ionization $\left(\Delta H_{\mathrm{i}}\right)$ of $1-\mathrm{X}, \mathrm{Y}$ in $\mathrm{BCl}_{3}$ / $\mathrm{CH}_{2} \mathrm{Cl}_{2}$ at $-70^{\circ} \mathrm{C}$ versus $\mathrm{p} K_{\mathrm{R}}+$ for equilibria of the same cations with their carbinols in aqueous $\mathrm{H}_{2} \mathrm{SO}_{4} . \Delta H_{\mathrm{i}}(1-\mathrm{OMe}, \mathrm{OMe})$ was derived from equilibrium studies and $\Delta H_{\mathrm{i}}(1-\mathrm{Me}, \mathrm{H})$ from conductivity experiments. The correlation equation $(r=0.997)$ is $\Delta H_{\mathrm{i}}=-96-6.3 \mathrm{p} K_{\mathrm{R}^{+}}(\mathrm{kJ} / \mathrm{mol})$.

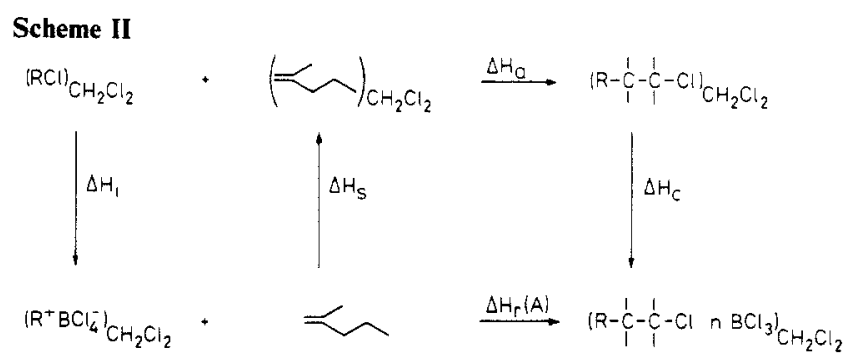

$\operatorname{dium}^{7 \mathrm{a}}\left[m\left(\mathrm{CH}_{2} \mathrm{Cl}_{2} / \mathrm{BCl}_{3}\right)=-6.3 \mathrm{~kJ} / \mathrm{mol} ; m^{\prime}\right.$ (superacid $)=-6.9$ $\mathrm{kJ} / \mathrm{mol}]$, while the intercepts $\left[b\left(\mathrm{CH}_{2} \mathrm{Cl}_{2} / \mathrm{BCl}_{3}\right)=-96 \mathrm{~kJ} / \mathrm{mol}\right.$; $b^{\prime}($ superacid $)=-250 \mathrm{~kJ} / \mathrm{mol}$ ) differ by a value close to $\Delta H_{\mathrm{t}}$.

2. Calorimetric Study of the Addition of Diarylmethyl Chlorides to Alkenes. Addition of Diarylmethyl Chlorides to 2-Methyl-1pentene. The addition of diarylmethyl chlorides to 2-methyl-1pentene in $\mathrm{CH}_{2} \mathrm{Cl}_{2}$ at $-70^{\circ} \mathrm{C}$ is selectively terminated after the formation of the $1: 1$ products. ${ }^{4,5}$ We have evaluated the heats of addition $\left(\Delta H_{\mathrm{a}}\right)$ in two different ways.

In approach $\mathrm{A}$ (Scheme II), a definite amount of neat alkene was added to an excess of completely ionized 1-X,Y. In order to obtain $\Delta \mathrm{H}_{\mathrm{a}}$ for the $\mathrm{CH}_{2} \mathrm{Cl}_{2}$-solvated components, we have to correct the observed heats of reaction $\left[\Delta H_{\mathrm{r}}(\mathrm{A})\right]$ for the heats of ionization of $1-\mathrm{X}, \mathrm{Y}\left(\Delta H_{\mathrm{i}}\right.$, see above $)$, the heats of solution of the alkene in $\mathrm{CH}_{2} \mathrm{Cl}_{2}\left(\Delta H_{\mathrm{s}}\right)$, and the complexation enthalpy $\left(\Delta H_{\mathrm{c}}\right)$ of the addition products with the Lewis acid (eq 3 ). The latter was determined by introducing $\mathrm{CH}_{2} \mathrm{Cl}_{2}$ solutions of the adducts 3-X,Y into mixtures of $\mathrm{CH}_{2} \mathrm{Cl}_{2} / \mathrm{BCl}_{3}$.

$$
\Delta H_{\mathrm{a}}=\Delta H_{\mathrm{r}}(\mathrm{A})+\Delta H_{\mathrm{i}}-\Delta H_{\mathrm{s}}(\text { alkene })-\Delta H_{\mathrm{c}}
$$

In approach $\mathrm{B}, \Delta H_{\mathrm{a}}$ was obtained by introducing samples of pure $\mathrm{RCl}$ into a solution of excess alkene in $\mathrm{CH}_{2} \mathrm{Cl}_{2} /$ Lewis acid (Scheme III). For the evaluation of $\Delta H_{\mathrm{a}}$, the heat of reaction $\Delta H_{\mathrm{r}}(\mathrm{B})$ has to be corrected for the heats of solution of $1-\mathrm{X}, \mathrm{Y}$ in $\mathrm{CH}_{2} \mathrm{Cl}_{2}\left(\Delta H_{\mathrm{s}}\right)$ and $\Delta H_{\mathrm{c}}(\mathrm{eq} 4) . \Delta H_{\mathrm{a}}$ ought to be further corrected

$$
\Delta H_{\mathrm{a}}=\Delta H_{\mathrm{r}}(\mathrm{B})-\Delta H_{\mathrm{s}}(\mathrm{RCl})-\Delta H_{\mathrm{c}}
$$




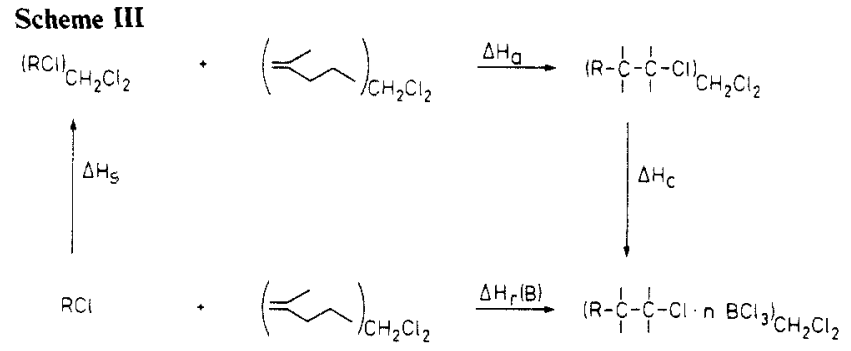

Table V. Heats of Addition of Anisylphenylmethyl Chloride (1-OMe,H) to Various Alkenes in $\mathrm{CH}_{2} \mathrm{Cl}_{2} / \mathrm{BCl}_{3}$ at $-70^{\circ} \mathrm{C}(\mathrm{kJ} / \mathrm{mol})$

\begin{tabular}{cccc}
\hline alkene & $\Delta H_{\mathrm{a}}{ }^{a}$ & $\Delta H_{\mathrm{r}}(\mathrm{A})^{b}$ & $\Delta H_{\mathrm{c}}{ }^{c}$ \\
\hline & $-84.5 \pm 3.6$ & & $-43.7 \pm 1.0$ \\
& $-78.9 \pm 3.8$ & $-80.6 \pm 2.2$ & $-47.1 \pm 1.0$ \\
& $-83.4 \pm 3.2$ & $-82.5 \pm 1.2$ & $-44.5 \pm 0.4$ \\
& $-78.1 \pm 4.4$ & $-77.8 \pm 3.2$ & $-45.1 \pm 0.7$ \\
& $-74.2 \pm 2.9$ & $-77.2 \pm 0.4$ & $-48.4 \pm 0.1$ \\
\hline
\end{tabular}

${ }^{a} \Delta H_{\mathrm{a}}$ evaluated according to Scheme II, procedure A. ${ }^{b}$ Heat of reaction between the carbenium ion and the $\mathrm{CH}_{2} \mathrm{Cl}_{2}$-solvated alkenes ' $\mathrm{Heat}$ of complexation of the $\mathrm{CH}_{2} \mathrm{Cl}_{2}$-solvated products by $\mathrm{BCl}_{3}$ in $\mathrm{CH}_{2} \mathrm{Cl}_{2}$ at $-70^{\circ} \mathrm{C}$.

for the enthalpy of interaction between alkene and Lewis acid. Since we found it not to exceed $4 \mathrm{~kJ} / \mathrm{mol}$, in line with studies on other Lewis acids, ${ }^{15}$ it has been disregarded.

Table IV shows that both pathways gave heats of addition of diarylmethyl chlorides to 2-methyl-1-pentene (average value, $\Delta H_{a}$ $=-86.5 \pm 2.7 \mathrm{~kJ} / \mathrm{mol}$ ) that are independent of the para substituents.

The slightly larger $\Delta H_{\mathrm{a}}$ values obtained by pathway $\mathrm{B}$ are probably due to a small degree of polymerization, because the heats of reaction moderately increased with increasing alkene concentrations when $\mathrm{BCl}_{3}$ was used for procedure B. Since polymerization does not take place in the $\mathrm{ZnCl}_{2} \cdot\left(\mathrm{OEt}_{2}\right)_{1.5}$ catalyzed ${ }^{16}$ reactions, the $\Delta H_{\mathrm{a}}$ value obtained with $\mathrm{ZnCl}_{2}$ from procedure B is in fair agreement with $\Delta H_{\mathrm{a}}$ of pathway $\mathrm{A}$.

Para-substituted diarylmethyl chlorides are related to systems with important anomeric interactions. ${ }^{17}$ Instead of the direct interaction between the geminally bonded groups $\mathrm{X}$ and $\mathrm{Y}$ with $\mathrm{Cl}$ as in $\mathrm{H}_{2} \mathrm{C}(\mathrm{X}) \mathrm{Cl}$ and $\mathrm{H}_{2} \mathrm{C}(\mathrm{Y}) \mathrm{Cl}$, a benzene ring separates both ligands from the anomeric center. The invariance of $\Delta H_{\mathrm{a}}$ with varying $X, Y$ indicates that such ground-state effects are small $(<3 \mathrm{~kJ} / \mathrm{mol})$, in line with recent $\mathrm{X}$-ray crystallographic evidence. ${ }^{18}$

The invariance of $\Delta H_{\mathrm{a}}$ for a set of related alkyl halides had been assumed earlier in the derivation of rules for the scope of aliphatic Friedel-Crafts alkylations. ${ }^{4 a-d}$

Addition of the Anisylphenyl Carbenium Ion to Different Alkenes. For the reaction of anisylphenyl carbenium ion $\mathbf{1}^{+}-\mathrm{OMe}, \mathrm{H}$ with different alkenes, $\Delta H_{\mathrm{a}}$ values between -74 and $-85 \mathrm{~kJ} / \mathrm{mol}$ were evaluated by procedure A (Scheme II; Table V).

Reaction 1 involves the conversion of a $\mathrm{CC}$ double bond into two $\mathrm{CC}$ single bonds. In accordance, $\Delta H_{\mathrm{a}}$ predominantly reflects the difference between the bond energy increments of two $\mathrm{CC}$ single $(2 \times 350 \mathrm{~kJ} / \mathrm{mol})$ and one $\mathrm{CC}$ double bond $(610 \mathrm{~kJ} / \mathrm{mol}) .{ }^{19}$

(15) (a) Halaska, V.; Pecka, J.; Marek, M. Makromol. Chem., Macromol Symp. 1986, 3, 3. (b) Gandini, A.; Cheradame, H. Adv. Polym. Sci. 1980 $34 / 35,105$.

(16) Mayr, H.; Striepe, W. J. Org. Chem. 1985, 50, 2995

(17) (a) Radom, L.; Hehre, W.; Pople, J. A. J. Am. Chem. Soc. 1972, 94 2371. (b) Dill, J. D.; Schleyer, P. v. R.; Pople, J. A. J. Am. Chem. Soc, 1976, 98, 1663. (c) Hehre, W. J.; Radom, L.; Schleyer, P. v. R.; Pople, J. A. Ab Initio Molecular Orbital Theory; Wiley: New York, 1985. (d) Schleyer, P. v. R.; Jemmis, E. D.; Spitznagel, G. W. J. Am. Chem. Soc. 1985, 107, 6393.

(18) Edwards, M. R.; Jones, P. G.; Kirby, A. J. J. Am. Chem. Soc. 1986. 108,7067 .
Preliminary force field studies showed that steric effects, the extent of alkyl halide substitution, and loss of alkene $\pi$-resonance usually make only a minor contribution to $\Delta H_{\mathrm{a}}$. Since steric effects and $\pi$-resonance contributions are small for the compounds investigated, the corresponding values of $\Delta H_{\mathrm{a}}$ fall within the same range.

3. Conclusion. A Correlation Equation of Carbon-Carbon Bond Formation. The heats of coordination $\left(\Delta H_{\text {coord }}\right)$ of different carbocations with various carbanions in benzonitrile, acetonitrile, ${ }^{3 a, b}$ and sulfolane $/ 3$-methylsulfolane ${ }^{3 \mathrm{c}}$ have previously been derived to follow eq 5 . The heat of the reaction of carbenium tetra$\Delta H_{\text {coord }}=$ const $+a \mathrm{p} K_{\mathrm{R}^{+}}+b \mathrm{p} K_{\mathrm{a}}=$

$$
-50.2+4.93 \mathrm{p} K_{\mathrm{R}^{+}}-4.92 \mathrm{p} K_{\mathrm{a}}(\mathrm{kJ} / \mathrm{mol})
$$

chloroborates with alkenes in $\mathrm{CH}_{2} \mathrm{Cl}_{2}$ yielding unionized adducts $3\left(\Delta H_{\mathrm{b}}\right)$ is given by eq 6 . Since the $\Delta H_{\mathrm{a}}$ values are almost $\Delta H_{\mathrm{b}}=\Delta H_{\mathrm{a}}-\Delta H_{\mathrm{i}}(\mathrm{RX})=\Delta H_{\mathrm{r}}(\mathrm{A})-\Delta H_{\mathrm{s}}($ alkene $)-\Delta H_{\mathrm{c}}$

constant when strong steric effects are absent and $\Delta H_{\mathrm{i}}$ is linearily correlated with $\mathrm{p} K_{\mathrm{R}^{+}}$, eq 6 is equivalent to eq 7 .

$$
\Delta H_{\mathrm{b}}=\text { const }^{\prime}+a^{\prime} \mathrm{p}_{\mathrm{R}^{+}}=9.5+6.3 \mathrm{p} K_{\mathrm{R}^{+}}(\mathrm{kJ} / \mathrm{mol})
$$

While the carbanion is replaced by a neutral nucleophile, the anion stability term $\left(\mathrm{p} K_{\mathrm{a}}\right)$ of eq 5 is omitted in eq 7 . The constants in eq 5 and 7 include a $\mathrm{C}-\mathrm{C}$ bond increment and an ion solvation term. In addition, the constant in eq 7 incorporates a $\mathrm{C}-\mathrm{Cl}$ bond increment, the enthalpy for the separation of $\mathrm{Cl}^{-}$from the complex anion and the interaction of $\mathrm{BCl}_{3}$ with the solvent. Whereas $a^{\prime}$, which is of similar magnitude as $a$ (eq 5), is expected to be almost invariant toward a change of solvent and counterion, const' will increase with increasing solvent polarity and increasing acceptor strength of the Lewis acid.

The free enthalpy of the carbenium tetrachloroborate additions is given by eq 8 .

$$
\begin{aligned}
& \Delta G_{\mathrm{b}}{ }^{\circ}=\Delta G_{\mathrm{i}}{ }^{\circ}-\Delta G_{\mathrm{i}}{ }^{\circ}(\mathrm{RX})= \\
& \Delta H_{\mathrm{a}}-\Delta H_{\mathrm{i}}(\mathrm{RX})-T\left(\Delta S_{\mathrm{a}}-\Delta S_{\mathrm{i}}\right)=\Delta H_{\mathrm{b}}-T\left(\Delta S_{\mathrm{a}}-\Delta S_{\mathrm{i}}\right)
\end{aligned}
$$

With the incremental system reported by Benson, ${ }^{20}$ the entropy of addition $\left(\Delta S_{\mathrm{a}}\right)$ for the reaction of diarylmethyl chlorides with 2-methyl-1-pentene is estimated to be $\Delta S_{\mathrm{a}}=-164 \mathrm{~J} / \mathrm{K} \cdot \mathrm{mol}$, and $\Delta S_{\mathrm{i}}$ was calculated to be approximately $-130 \mathrm{~kJ} / \mathrm{mol}$ (see above). Substitution of these numbers in eq 8 yields eq 9 .

$$
\Delta G_{\mathrm{b}}^{\circ}=16+6.3 \mathrm{p} K_{\mathrm{R}^{+}}\left(\mathrm{kJ} / \mathrm{mol} \text { at }-70^{\circ} \mathrm{C}\right)
$$

Since $\Delta H_{\mathrm{a}}$ and $\Delta S_{\mathrm{a}}{ }^{20}$ and probably $\Delta S_{\mathrm{i}}$ fall into the same range for a variety of alkyl halides and alkenes, the addition of carbenium tetrachloroborates to alkenes is thermodynamically unfavorable in $\mathrm{CH}_{2} \mathrm{Cl}_{2}$ at $-70^{\circ} \mathrm{C}$, if $\mathrm{p} K_{\mathrm{R}^{+}}>-2.6$. Different values are obtained when steric interactions cannot be neglected and when the products are stabilized by complexation with the Lewis acid.

We are currently investigating the influence of alkene and alkyl halide variation on $\Delta H_{\mathrm{a}}$ and $\Delta G_{\mathrm{a}}{ }^{\circ}$ by force field methods.

\section{Experimental Part}

General Procedures. Diarylmethyl chlorides 1-X,Y and their alkene addition products were prepared according to literature procedures. $4 \mathrm{~b}, 11$ Alkenes were distilled over $\mathrm{LiAlH}_{4}$ prior to use or employed as purchased (isoprene, styrene; Aldrich Gold Label). For the equilibrium studies, gaseous $\mathrm{BCl}_{3}(99.9 \%$, Messer Griesheim) was transferred via gas-tight syringes. For calorimetric studies, a $1 \mathrm{M}$ solution of $\mathrm{BCl}_{3}$ in $\mathrm{CH}_{2} \mathrm{Cl}_{2}$ (Aldrich) was used. The $\mathrm{ZnCl}_{2} \cdot\left(\mathrm{OEt}_{2}\right)_{x}$ catalyst was prepared according to ref 16. $\mathrm{CH}_{2} \mathrm{Cl}_{2}$ was subsequently stirred over $\mathrm{CaCl}_{2}$, concentrated sulfuric acid, and $\mathrm{K}_{2} \mathrm{CO}_{3}$ and then distilled over $\mathrm{P}_{4} \mathrm{O}_{10}$ and finally $\mathrm{Na}-\mathrm{Pb}$ alloy (Fluka). $\mathrm{CD}_{2} \mathrm{Cl}_{2}$ was stored over $\mathrm{Na}-\mathrm{Pb}$ alloy prior to use. NMR spectra were obtained on a Varian XL-200 spectrometer. Chemical shifts are reported relative to $\mathrm{Si}\left(\mathrm{CH}_{3}\right)_{4}$. Errors given are mean standard deviations of measured quantities. Errors of derived data have been evaluated according to laws of propagation of errors.

Equilibrium Studies. Partial ionization of the mixtures of the alkyl halides is usually obtained by adding $0.5-1$ equiv of $\mathrm{BCl}_{3}$ in $\mathrm{CD}_{2} \mathrm{Cl}_{2}$ at $-70^{\circ} \mathrm{C}$. ' $\mathrm{H}$ NMR spectral data are given in the supplementary material.

(19) Streitwieser, A., Jr.; Heathcock, C. H. Introduction to Organic Chemistry; Macmillan: New York, 1981; p 1195.

(20) Benson, S. W. Thermochemical Kinetics; Wiley: New York, 1976. 
Typical example: $p$-Anisyl( $p$-phenoxyphenyl)methyl chloride (1$\mathrm{OMe}, \mathrm{OPh} ; 40.2 \mathrm{mg}, 0.124 \mathrm{mmol}$ ) and $p$-anisyl-p-tolylmethyl chloride (1-OMe,Me; $72.4 \mathrm{mg}, 0.293 \mathrm{mmol}$ ) were dissolved in $0.6 \mathrm{~mL}$ of $\mathrm{CD}_{2} \mathrm{Cl}_{2}$ in an NMR tube. $1,1,2,2-$ Tetrachloroethane $(20.0 \mu \mathrm{L}, 31.5 \mathrm{mg}, 0.188$ $\mathrm{mmol}$ ) was added as standard. Partial ionization of the mixture is accomplished by addition of $2.3 \mathrm{~mL}(0.094 \mathrm{mmol})$ of $\mathrm{BCl}_{3}$ gas at $-70^{\circ} \mathrm{C}$. The signals of para methyl $\left(\delta=2.33,1-\mathrm{OMe}, \mathrm{Me} ; \delta=2.58,1^{+}\right.$. OMe,$\mathrm{Me})$, para methoxy $\left(\delta=3.75,1-\mathrm{OMe}, \mathrm{Me}, 1-\mathrm{OMe}, \mathrm{OPh} ; \delta=4.14,1^{+}\right.$. $\mathrm{OMe}, \mathrm{OPh} ; \delta=4.22,1^{+}$-OMe, $\left.\mathrm{Me}\right)$, and methine protons $(\delta=6.14$, 1-OMe,OPh; $\delta=6.17,1$-OMe, Me; $\delta=8.94,1^{+}-\mathrm{OMe}, \mathrm{OPh} ; \delta=9.13$, $1^{+}$-OMe,Me) in both carbenium ion and precursors were recorded with those of tetrachloroethane $(\delta=6.01)$. The signal integrals gave nine equations for the determination of the concentrations of 1.OMe,OPh, $1^{+}-\mathrm{OMe}, \mathrm{OPh}, \mathbf{1}-\mathrm{OMe}, \mathrm{Me}$, and $\mathbf{1}^{+}-\mathrm{OMe}, \mathrm{Me}$. Regression analysis ${ }^{21} \mathrm{led}$ to $K_{203}=0.0480$ and $\Delta G_{203}{ }^{\circ}=5.13 \mathrm{~kJ} / \mathrm{mol}$. Further determinations of $\Delta G_{203}{ }^{\circ}$ for six different samples $\left(\Delta G_{203}{ }^{\circ}=4.84,5.15,5.36,4.71,5.02\right.$, $5.60 \mathrm{~kJ} / \mathrm{mol}$ ) gave an average value of $\Delta G_{203}^{\circ}=5.1 \pm 0.3 \mathrm{~kJ} / \mathrm{mol}$.

Calorimetric Studies. General Procedures. A calorimeter of the type previously described ${ }^{22}$ was used with minor modifications. Experimental details and procedures closely followed the description given there ${ }^{22}$ if not otherwise reported. Each measurement was repeated at least twice. A determination of the heat capacity of the calorimeter was undertaken before and after every calorimeter run. The reliability of the data was checked independently by the determination of the heat of interaction of tetrahydrofuran with $\mathrm{SbCl}_{5}$ in $\mathrm{CH}_{2} \mathrm{Cl}_{2}$ at $-55^{\circ} \mathrm{C}^{23}$ All further determinations were run in $\mathrm{CH}_{2} \mathrm{Cl}_{2}$ at $-70^{\circ} \mathrm{C}$.

(21) Hainer, K. Numerik mit BASIC Tischrechnern; Teubner: Stuttgart, 1983; p 178.

(22) Arnett, E. M.; Petro, C. J. Am. Chem. Soc. 1978, 100, 5402

(23) Gutmann, V.; Wychera, E. Inorg. Nucl. Chem. Lett. 1966, 2, 257.
Heats of Addition of Diarylmethyl Chlorides to 2-Methyl-1-pentene. A $1 \mathrm{M}$ solution of $\mathrm{BCl}_{3}$ in $\mathrm{CH}_{2} \mathrm{Cl}_{2}(10 \mathrm{~mL})$ or of $\mathrm{ZnCl}_{2} \cdot\left(\mathrm{OEt}_{2}\right)_{1.5}$ in $\mathrm{CH}_{2} \mathrm{Cl}_{2}(5 \mathrm{~mL})$ was added to a solution of the alkene $(\approx 1 \mathrm{mmol})$ in $\mathrm{CH}_{2} \mathrm{Cl}_{2}\left(\approx 10^{-2} \mathrm{M}\right)$. The heat of reaction upon introduction of $0.50-0.75$ $\mathrm{mmol}$ of the neat diarylmethyl chloride was recorded. Heats of solution of the diarylmethyl chlorides in $\mathrm{CH}_{2} \mathrm{Cl}_{2}$ were determined separately.

Heats of Addition of Diarylcarbenium Ions to Alkenes. Ampules of less than stoichiometric amounts $(0.2-2 \mathrm{mmol})$ of the alkene were in troduced into a $10^{-3}-10^{-2} \mathrm{M}$ solution $(\approx 200 \mathrm{~mL})$ of the carbenium tetrachloroborates. For 2-methyl-1-pentene the integral heat of solution in $\mathrm{CH}_{2} \mathrm{Cl}_{2}$ was determined subsequently. All other alkenes have been introduced as $5-20 \%$ solutions in $\approx 1 \mathrm{~mL}$ of $\mathrm{CH}_{2} \mathrm{Cl}_{2}$ and heats of dilution were neglected.

Heats of Interaction with $\mathrm{BCl}_{3}$. Solutions of the addition products in $\approx 1.5 \mathrm{~mL}$ of $\mathrm{CH}_{2} \mathrm{Cl}_{2}$ were sealed in an ampule. The heat of reaction upon its introduction into excess $\mathrm{BCl}_{3} / \mathrm{CH}_{2} \mathrm{Cl}_{2}$ was recorded.

Acknowledgment. This work was supported by the Deutsche Forschungsgemeinschaft and the Fonds der Chemischen Industrie at Lübeck, the Duke Chemistry Department, and National Science Foundation Grant No. CHE-8641817 to E.M.A. at Durham. C.S. gratefully acknowledges help by John Harrelson and Frank Fisher and financial assistance of the Fonds der Chemischen Industrie/Stiftung Volkswagenwerk by a Kekulê grant.

Supplementary Material Available: ${ }^{1} \mathrm{H}$ NMR spectral data for diarylmethyl chlorides $1-\mathrm{X}, \mathrm{Y}$ and diarylcarbenium tetrachloroborates in $\mathrm{CD}_{2} \mathrm{Cl}_{2}$ at $-70^{\circ} \mathrm{C}$ and compilations of $\mathrm{NMR}$ spectroscopic determinations of $K$ and $\Delta G^{\circ}$ (5 pages). Ordering information is given on any current masthead page.

\title{
Host-Guest Complexation. 45. A Highly Preorganized Chromogenic Spherand Indicator System Specific for Sodium and Lithium Ions ${ }^{1}$
}

\section{Donald J. Cram," Richard A. Carmack, and Roger C. Helgeson}

Contribution from the Department of Chemistry and Biochemistry, University of California, Los Angeles, California 90024. Received July 9, 1987

\begin{abstract}
The synthesis and chromogenic properties of 1 as a sodium and lithium ion selective indicator system are described The $\mathrm{p} K_{\mathrm{a}}$ values of 1 in the absence and presence of various metal ions were measured in $80 \%$ dioxane-20\% water $(\mathrm{v} / \mathrm{v})$. Observed values were as follows: $\mathrm{Li}^{+}, 5.9 ; \mathrm{Na}^{+}, 6.9 ; \mathrm{K}^{+}, 12.7 ; \mathrm{Ca}^{2+}, 12.8 ; \mathrm{Mg}^{2+}, 13.2 ; 1,5$-diazabicyclo[4.3.0]non-5-ene (DBN), 13.0 . The noncomplexing model system 21 gave a $\mathrm{p} K_{\mathrm{a}}$ of 10.8 in the same medium. Spherand 1 is yellow $\left(\lambda_{\max } 396 \mathrm{~nm} ; \epsilon_{\max } 17500\right.$ $\mathrm{L} /(\mathrm{mol} \cdot \mathrm{cm}))$, whereas spheraplexes $1^{-} \cdot \mathrm{Li}^{+}\left(\lambda_{\max } 586 \mathrm{~nm}, \epsilon_{\max } 35500 \mathrm{~L} /(\mathrm{mol} \cdot \mathrm{cm})\right)$, and $1^{-} \cdot \mathrm{Na}^{+}\left(\lambda_{\max } 596 \mathrm{~nm}, \epsilon_{\max } 35500\right.$ $\mathrm{L} /(\mathrm{mol} \cdot \mathrm{cm}))$ as well as uncomplexed $1^{-}\left(\lambda_{\max } 610 \mathrm{~nm}, \epsilon_{\max } 53000 \mathrm{~L} /(\mathrm{mol} \cdot \mathrm{cm})\right)$ are deep blue or violet in $80 \%$ dioxane-20\% water $(v / v)$ and other solvents. Thus 1 is a chromogenic ion-selective indicating system capable of detecting $\mathrm{Li}^{+}$and $\mathrm{Na}^{+}$ at concentrations as low as $10^{-8} \mathrm{M}$ in the presence of other common ions. The binding free energies of spherands 4-6 binding lithium picrate and sodium picrate at $25^{\circ} \mathrm{C}$ in $\mathrm{CDCl}_{3}$ saturated with $\mathrm{D}_{2} \mathrm{O}$ were measured and found to range between 8.4 and $12.5 \mathrm{kcal} \mathrm{mol}^{-1}$, somewhat higher than those for 7 , but much lower than those for 2 .
\end{abstract}

This paper describes the synthesis and properties of 1 as an ion-selective chromogenic indicator system for $\mathrm{Na}^{+}$and $\mathrm{Li}^{+}$. The binding properties and ion selectivities of analogues 2-8 are compared.

Spherand 2 binds lithium, sodium, and potassium picrates at $25^{\circ} \mathrm{C}$ in $\mathrm{CDCl}_{3}$ saturated with $\mathrm{D}_{2} \mathrm{O}$ with $-\Delta G^{\circ}$ values of $>23$, 19.3 , and $<6 \mathrm{kcal} \mathrm{mol}^{-1}$. The very strong binding of $\mathrm{Li}^{+}$and $\mathrm{Na}^{+}$ and nondetectable binding to $\mathrm{K}^{+}$have been attributed to the high complementarity and preorganization of the cavity in $2 .^{2}$ The

(1) We gratefully acknowledge support of this research from the Division of Basic Sciences of the Department of Energy.

(2) Cram, D. J.; Lein, G. M. J. Am. Chem. Soc. 1985, 107, 3657-3668. crystal structure of 2 shows it contains a hole lined with 24 electrons having a diameter between that of $\mathrm{Li}^{+}$and $\mathrm{Na}^{+}$. The six octahedrally arranged oxygens defining the cavity are shielded from solvation by six aryl and six methyl groups to provide a microdielectric environment for complexation between that of a vacuum and that of a hydrocarbon. The potassium ion is too large to enter this structurally defined cavity. Divalent ions of small enough diameters (e.g., $\mathrm{Mg}^{2+}$ or $\mathrm{Ca}^{2+}$ ) do not enter this cavity because of their very high heats of hydration. ${ }^{3,4}$

(3) Cram, D. J.; Kaneda, T.; Helgeson, R. C.; Brown, S. B.; Knobler, C. B.; Maverick, E.; Trueblood, K. N. J. Am. Chem. Soc. 1985, 107, 3645-3657.

(4) Cram, D. J. Angew. Chem., Int. Ed. Engl. 1986, 25, 1039-1067. 